\title{
Intersections
}

Canadian Journal of Music

Revue canadienne de musique

\section{Brian Cherney: Collaborator and Composer}

\section{John Beckwith}

Volume 37, numéro 1, 2017

Illuminations: Essays in Honour of Brian Cherney

URI : https://id.erudit.org/iderudit/1059884ar

DOI : https://doi.org/10.7202/1059884ar

Aller au sommaire du numéro

\section{Éditeur(s)}

Canadian University Music Society / Société de musique des universités canadiennes

ISSN

1911-0146 (imprimé)

1918-512X (numérique)

Découvrir la revue

Citer cet article

Beckwith, J. (2017). Brian Cherney: Collaborator and Composer. Intersections, 37(1), 19-29. https://doi.org/10.7202/1059884ar

\section{Résumé de l'article}

Cet article inclut des commentaires sur certaines compositions de Cherney et un compte rendu de sa contribution à l'ouvrage intitulé Weinzweig: Essays on His Life and Music (Waterloo, Wilfrid Laurier University Press, 2011), dont il a été coéditeur en collaboration avec John Beckwith. Son approche de la composition prépare bien Cherney au traitement d'un vaste éventail de questions musicales, tandis que sa connaissance poussée de l'histoire de l’Allemagne et des Juifs (que révèlent par exemple sa dissertation présentée à l'Université de Toronto sur la controverse Bekker-Pfitzner de 1919 et son essai sur les sources du radicalisme de Weinzweig incluse dans la publication de 2011) révèle des pistes d'exploration dans son travail de création. D'autres observations portent sur son don pour la parodie et les blagues musicales pour initiés.
Copyright @ C Canadian University Music Society / Société de musique des universités canadiennes, 2019
Ce document est protégé par la loi sur le droit d'auteur. L'utilisation des services d'Érudit (y compris la reproduction) est assujettie à sa politique d'utilisation que vous pouvez consulter en ligne.

https://apropos.erudit.org/fr/usagers/politique-dutilisation/ 


\title{
BRIAN CHERNEY: COLLABORATOR AND COMPOSER
}

\author{
John Beckwith
}

My collaboration with Brian Cherney in the 2011 publication Weinzweig: Essays on His Life and Music was the result of a conversation we had in 2006 after we visited the composer John Weinzweig in Toronto in the seniors' home where he and his wife Helen were then living. Weinzweig was ninety-three years old. As former students of his, Brian and I agreed that his music and his career deserved an updated book-length treatment, but since neither of us felt ready to produce one on our own, we decided to do it together. We were able to tell Weinzweig of our decision, and he seemed happy about it, but he died before its realization. The book contains chapters by twelve writers, including the two editors, and three other specialists helped with preparing a works list, a discography, and an accompanying CD of selected examples of Weinzweig's music. Tracing my correspondence files, I'm reminded of our development of an outline of topics, and then of our extended work, researching our own assignments and dealing with our talented contributors. With one scheduled topic, we were unable to find a suitable contributor, despite several attempts. The committed contributors varied in their responses-to deadlines and to editorial suggestions: several were world-class procrastinators; a few were affronted by what they saw as our interference. Brian's perseverance in dealings with the staff at Library and Archives Canada in Ottawa, home of the Weinzweig Fonds, was a major factor in the success of the project. The final product achieved what we had hoped for: the Wilfrid Laurier University Press produced a handsome volume, and its launch in January 2011 was well received. As William Littler noted in a Toronto Star column about the book, it is the first Weinzweig study to have benefitted from the newly-established Fonds in Ottawa.

Brian and I wrote the opening biographical chapter together, and it contains not only some fresh illustrations but also some previously unresearched aspects. His own chapter is a thorough and highly original examination of Weinzweig's activism. In it he traces this strong personality streak from the composer's early conducting efforts and writings, through his growing presence as a compositional figurehead and organizer. Noting that Weinzweig's father had been a member of the early twentieth-century Bund movement in Eastern Europe, and that the Peretz Workman's Circle, where Weinzweig 
had some of his earliest childhood exposures to music, was the North American extension of that movement, he concludes that what he calls the "Bundist ideology" of activism was absorbed by Weinzweig both in the home environment and at the Peretz School. Recognizing CBC Radio as the constant target of many of Weinzweig's critical campaigns, he ends by imagining Weinzweig's reaction to more recent $\mathrm{CBC}$ music policies.

Our friendship goes back many years before that collaboration. I first knew Brian when he was a teenage music student at the University of Toronto. The late 1950s and early 196os (just before the move of the Faculty of Music into the Edward Johnson Building) were memorable for me as a teacher of music history and music theory at the Faculty. I worked with an outstanding group of young talents, many of whom went on to important musical careers. Among them were the flutist and composer Robert Aitken, the composer and pianist Bruce Mather, the pianists William Aide and Pierrette LePage, and the soprano Teresa Stratas. At this period also, the Royal Conservatory principal, Ettore Mazzoleni, set up a scholarship plan for students in their mid-teens who looked likely to be headed for professional studies, and conscripted two Faculty members, Talivaldis Kenins and me, to give classes in basic musicianship to prepare them. These kids were also stimulating to teach, and among those who rose to prominence were Patricia Perrin (later Krueger), the resident pianist of the Toronto Symphony Orchestra for many years, Terry Helmer, violist of the Orford String Quartet, and ... Brian Cherney. Brian struck me in this company as an intelligent and extraordinarily serious young musician. I followed his maturing in the next decade into a distinctive compositional voice and critical writer.

We first collaborated in the early 1970s, when I was general editor of a series of Canadian-composer studies sponsored by the Canadian Music Centre. The first volume was a life-and-works of Harry Somers, who turned fifty in 1975, and Brian was the assigned writer. His book (Cherney 1975) established a benchmark for succeeding works in the series: there were to have been many, but for various reasons only four were issued. He developed the model of thorough biographical account and illustrated survey of repertoire that no previous book on a composer in Canada had ever achieved. Its novelty and seriousness of scope received no recognition from the prominent critic John Kraglund, who panned it (Kraglund 1975). As general editor, I wrote a letter of protest, in which I noted that the preface indicated it was a book for "musicians and music lovers" and that Kraglund's several decades on the music desk of the Globe and Mail were evidence that he belonged to neither category (Beckwith 1975). Brian is currently working on an update of the Somers book, and it will surely be another important contribution to our musical annals.

Cherney's major musicological study of the late 196os and early 1970 is his University of Toronto doctoral dissertation "The Bekker-Pfitzner Controversy (1919-1920): Its Significance for German Music Criticism during the Weimar Republic (1919-1932)," about which Robin Elliott writes more fully in this issue. Cherney's exceptionally detailed research on this famous aesthetic debate includes critical examples from the entire Weimar period, demonstrating how 
the reactionary views of the Pfitzner camp, tinged with anti-Semitism, foreshadow the policies that were inscribed in law under the Nazis. This important achievement had a lasting effect on Cherney's creative work, not only in his occasional choice of topics and sources-the diary of a Holocaust victim, Elly Hillesum (An Unfinished Life), the writings of the Romanian poet Paul Celan-but also his approach to "abstract" considerations such as texture and dynamics.

Now I want to approach Cherney's compositions. Perhaps a way to start is by noting some of his quotations. The Fourth Quartet was written in 1995, the fiftieth anniversary of the end of World War II, and among several references are some phrases from Bartók and part of a wartime song, "Lili Marlene," popularized by Marlene Dietrich. That tune is particularly touching in a few quiet moments just before the end. New poems are created from old poems, says T.S. Eliot, and new music often refers to older music, even if not in an easily recognizable way. The choral work An Unfinished Life (2007) incorporates, almost in its entirety, one of J.S. Bach's songs with figured bass. In the third of the five piano pieces entitled Dans le crépuscule du souvenir (1980) there are quotations from Schubert's piano music - the first Impromptu and the last Moment Musical (the same two citations that occurred a few years before in the chamber work Group Portrait-with Piano, 1978). The composer in his notes for the Fourth Quartet doesn't say which Bartók pieces that work refers to, but in a more recent score, Die klingende Zeit (1994) three quotations are identified: the song "Um Mitternacht" in Mahler's Rückert cycle, the passacaglia called "Nacht" in Pierrot Lunaire by Schoenberg, and the piano piece "La Vallée des cloches" from the suite Miroirs by Ravel. Of these only the Ravel is easy to pick up aurally. The purpose of such recollections isn't always ready aural recognition; for Cherney they may represent a connection, a point of departure in his creative process.

To probe the distinctiveness of Cherney's music, I have a suggestion: go to the piano and play five of the seven highest notes together with five of the seven lowest notes, pressing those keys with your fingers as gently as you can. That's the cluster that begins his piano work The Stillness of the Seventh Autumn (1983). It is preceded by seven seconds of silence, and the chord itself is marked quadruple pianissimo-no fewer than four lower-case ps. This "stillness" is meant to be scarcely detected by human ears. Verdi marks the final chord in his Requiem similarly, and that's generally considered an extreme compositional command. Brian Cherney has sometimes written six ps, for example in Group Portrait-with Piano and again several times in Dans le crépuscule du souvenir. Quadruple pianissimo markings are found in many if not most Cherney works besides the Seventh Autumn: a few examples are the beginnings of Quartets 3 and 5, the beginnings and endings of Quartets 4 and 6, and the endings of Quelquefois à l'ombre de la nuit au lointain (1991), and Die klingende Zeit-not that this trademark dynamic is confined to openings and closings; there are innumerable instances in interior passages. By contrast, I found only one quadruple fortissimo indication (in the Group Portrait score); he may have 
written further loud passages with more than three lower-case fs, but it seems only very rarely.

To my ears there's something distinctive about Cherney's textures. In the string quartets he often marks a line "quasi cadenza," and the line stands out appropriately-but not always by itself; more often it is accompanied by other sounds. It is surprising how frequently in the quartets all four instruments play in the same register, making a unified texture rather than one where individual voices stand out. There are many comparable passages in his works for mixed ensembles and for orchestra. In the large wind-ensemble score Quelques espaces entre les anges et la terre (2006) there are frequent gestures by groups of mixed instrumentation-for example, piccolos, flutes, clarinets, and saxophones overlapping in an ensemble timbre rather than more-easily-identified single colours. Gillian MacKay, conductor of the premiere of that piece, wrote a short article about it, noting among other things that it illustrates Cherney's "lifelong fascination with clocks"; one section, she says, resembles "a room full of clocks, independently accounting for the passage of time" (MacKay 2006).

Some years ago when visiting the Cherneys' home in Montreal I noticed in their living room a number of books about the history of clocks and also copies of a couple of periodicals about watch-making. Robert Aitken told me that when Brian visited him in Freiburg where he was teaching, Brian took several train trips over the short distance across the Swiss border to Basle, in order to check out clock and watch centres there. When I asked Brian about this "fascination," he said, "For many years I have had a keen interest in mechanical watches and I have collected a number of vintage Omegas from the 1940 s to the late 1960 ... . I subscribe to two German watch magazines which keep me up to date on new developments in the design and manufacture of mechanical movements, since there have been many innovations in recent years .... I have a pretty nice collection of both vintage and modern watches. So my interest is both aesthetic and technical" (Cherney email communication 26 September 2017).

The work that most reflects all this is Die klingende Zeit (1994; the composer's English translation of the title is "The music of time") for solo flute and chamber ensemble. It has a number of similarities to the Fourth Quartet, written around the same time. The composer's notes on the Quartet draw attention to a structural division of four equal parts, each six-and-a-half minutes long. Six-and-a-half is half of thirteen, and this may be a reminder of the thirteen weeks of each quarter-year: is this Cherney's response to the Four Seasons of Vivaldi? Die klingende Zeit has, more recognizably, a tripartite form, marked by something like clock-bells tolling, and each division lasts six-and-a-half minutes. The divisions represent not three of the four quarters of the year but three-quarters of a twenty-four-hour day, so we learn from the preface. The connection with clocks is deliberate, as becomes clear towards the end of the score when graphic illustrations appear, including (figure 1) a magnificent 


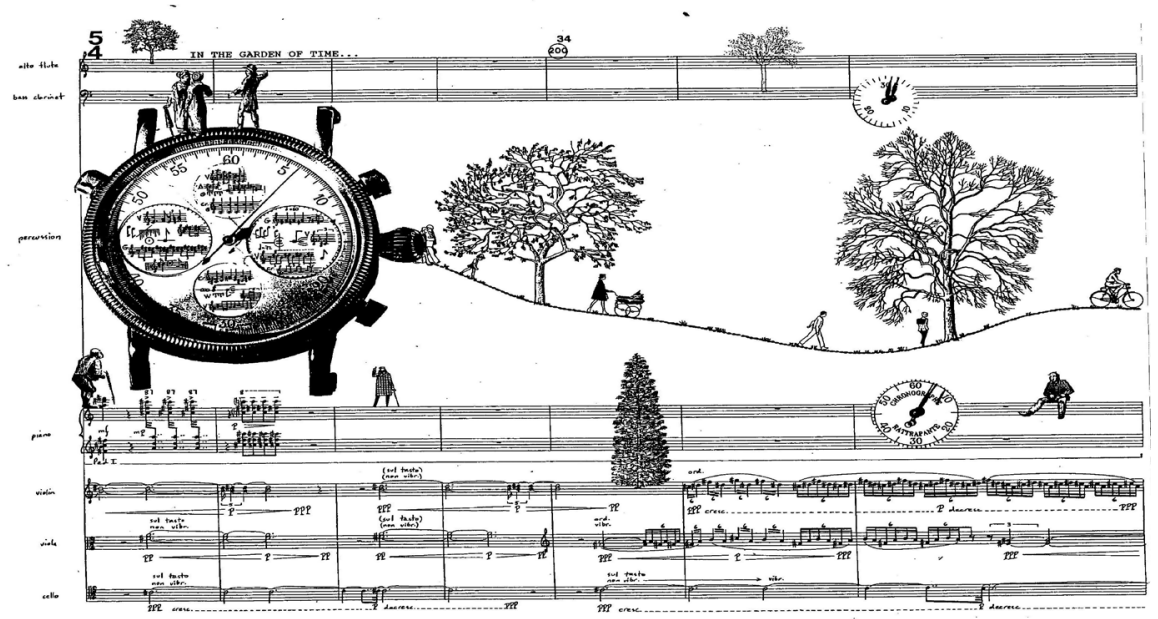

Figure 1. Cherney, Die klingende Zeit, 34

watch face in which short musical ideas are notated. ${ }^{1}$ This turns out to be an instruction to the percussionist of the ensemble to improvise for the next pageand-a-half on the specified instruments and notated gestures, creating what Cherney calls "a very soft tapestry of sound."

The specific timepiece illustrated is the "minute repeater," which in Cherney's estimation "stands unchallenged as the supreme achievement of traditional watchmaking" (Cherney 2002, 3). Another illustration, alongside the preface to the composer's manuscript version of the score, shows its mechanism. ${ }^{2}$ On the rhythmic and timbral organization outlined above, the composer writes in the preface,

The title $\ldots$ is a reference to the ways in which the passage of time has been made audible in the West since the invention of the mechanical clock during the Middle Ages. At first, bells were rung to signal the hours of prayer ("canonical hours") ... but with the invention of smaller clocks suitable for use in the home in the early fifteenth century, the sound of bells and chimes marking the passing of time became part of domestic life. The invention of the "repeater watch" by Daniel Quare during the 168 os made it possible for the owner of such a watch to "hear" the time upon demand: by pushing a special slide piece on the side of the watch, one could cause the watch to "chime" the hours and quarter hours ... . In the twentieth century, the "repeater" mechanism has been sufficiently miniaturized to be placed in wristwatches. (Cherney 2002, 2)

1 Figure 1 is from the composer's manuscript version of the score; a somewhat different illustration appears in the published version of the score (Cherney 2002, 49).

2 In the published version of the score, the illustration of the minute repeater mechanism appears not beside the preface, but rather in the score itself (Cherney 2002, 50). 
In an exceptionally detailed analysis of this work, Neil Middleton comments, "Though the rhythms are placed at important structural points ..., they are seldom noticeable because they are worked into the overall rhythmic texture of the piece .... In this manner Cherney intertwines clock time with the flow of musical time, creating a sense that one disappears into the other" (Middleton 2008, 230-1).

The word stillness occurs in five or more of Cherney's titles. Five mention one or more angels. Other featured terms are shadow, twilight, solitude, and distance. Languages of the titles vary: there are a more or less equal number in each of English, German, and French.

Speaking of titles, what are we to make of Trois pièces desséchées en forme de sandwich for viola and piano (1979)? Significantly, a quotation from Erik Satie appears as an epigraph to the second piece. The first piece is straightforward except for its frequent changes of metronome marking; the viola's last notes are marked quintuple pianissimo. But, turning to No. 2 (the filling of the sandwich), we are faced with an elaborate graphic score (figure 2).

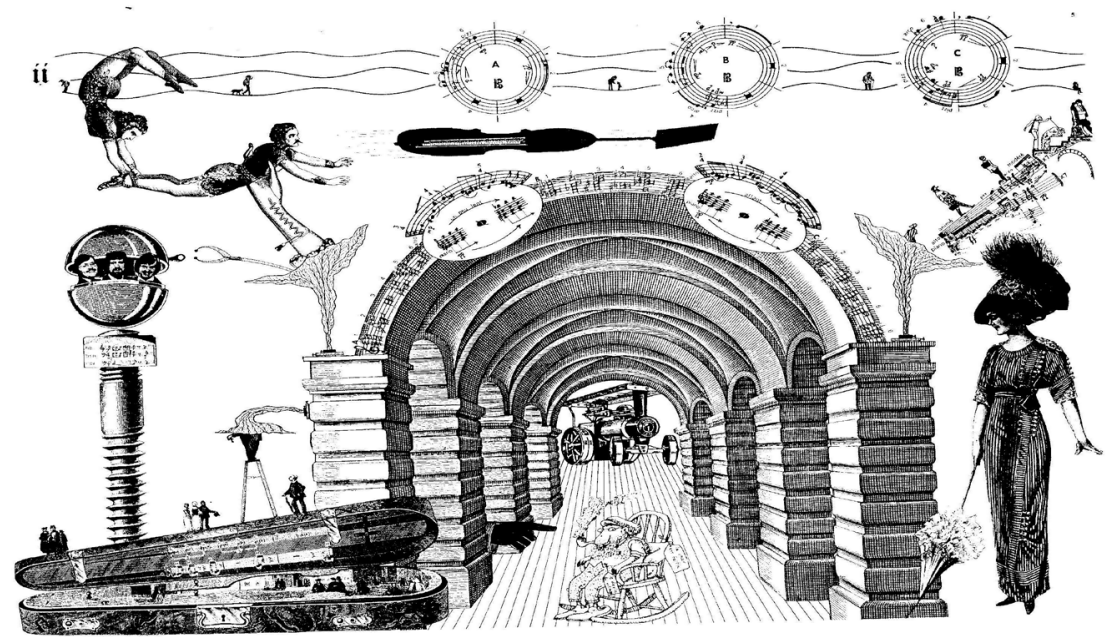

Figure 2. Cherney, Trois pièces desséchées en forme de sandwich, no. 2, 5

A woman in an enormous hat surveys a huge archway or tunnel, embroidered with musical indications and pointers to other musical fragments elsewhere on the page. At one end of the tunnel is a locomotive; at the other, an elderly man sits in a rocking chair smoking a pipe. The man is identified as "le devin du village" (after Rousseau), and the chair displays the motto "the flesh is weak" (no doubt a pun on the French word for flesh, chaire). On the rest of the page are a pair of acrobats, a violin with a piano keyboard imposed, and a string-instrument case with further musical fragments and part of a street scene-and everywhere human figures of various sizes. In one corner is a phrase to be played by oboe, bassoon, and horn, topped by three faces of members of the York Winds quintet, one of them being the composer's brother, 
Lawrence, the oboist of that ensemble. Piece No. 3 is mostly more conventional, but towards the end there are a few further graphics: a gentleman in a Homburg and overcoat gazes after a group of figures descending a hill off the page. A flower-like bunch of four staves droops above them; the staves are marked to be played by an oboe, a clarinet, and three bassoons. There are no Satie-esque captions in this score, but the unusual notation is otherwise quite in his spirit.

The fancy, the skittishness, here recalls Group Portrait-with Piano, although in this work of the previous year, 1978, there are as yet no illustrations. The five wind players wear specific costumes and enact an elaborate comic scenario. In the end, a costumed figure emerges from the audience with a camera and poses the players for a flash portrait. There is no pianist: the piano is there simply as part of the stage setting, and the horn plays a few phrases into its sound-board. In his introduction, the composer refers to the score as "a cheap piece of theatrical and musical entertainment," and adds, "There is irony but no depth, symbolism but no meaning, form but no content."

Once when Brian was visiting my home in Toronto he showed me a sketch of a multilingual skit about Brahms that he was putting together. It made fun of the scant evidence we have of Brahms's love life, but more serious images and quotations dealt with the history of Jewish life in Austria in Brahms's time. The pages showed scraps of dialogue to be included in bubbles, as in a comic strip, and suggested illustrations from various sources. It was unusual, but I didn't grasp that it was intended to be a musical score. When, just lately, I asked Brian about it, he sent me a score of his music-theatre work Brahms and the German Spirit (2009), with a DVD of a live performance. The work calls for a clarinet and a cello and (optionally) a third instrumentalist, a pianist dressed up as Brahms. The two players are asked to perform a scenario of actions and attitudes, and the work contains excerpts from Brahms's Trio Opus 114 for clarinet, cello, and piano, as well as passages suggesting the Klezmer style. Unusually for a composer, Cherney writes in his preface, "The score itself is intended to be sufficiently interesting that the piece ... does not need to be performed." Indeed, the score is a major example of his graphic-score method, and I think one could almost call it a "graphic novel."

Brian refers to his method as "collage." When I asked him for some details about it, this is what he said,

While in England in 1978-79 I used to go to flea markets where you could buy pages from 18th-century periodicals and other publications. I do not remember why I started to collect these but I also began to save images from a variety of sources-the BBC Times, newspapers, anything that might be useful for pieces. Even postcards with women dressed in late nineteenth-century clothes, with beautiful hats, etc ... . For the Brahms piece I found photographs of Brahms and other figures, including a wonderful book of photographs of Eastern European Jews, and these proved to be very useful .... [All t]hese I inserted, glued, joined to my scores once the music was copied. I am very adept at using an exacto knife as a result. (Cherney email communication 16 September 2017) 


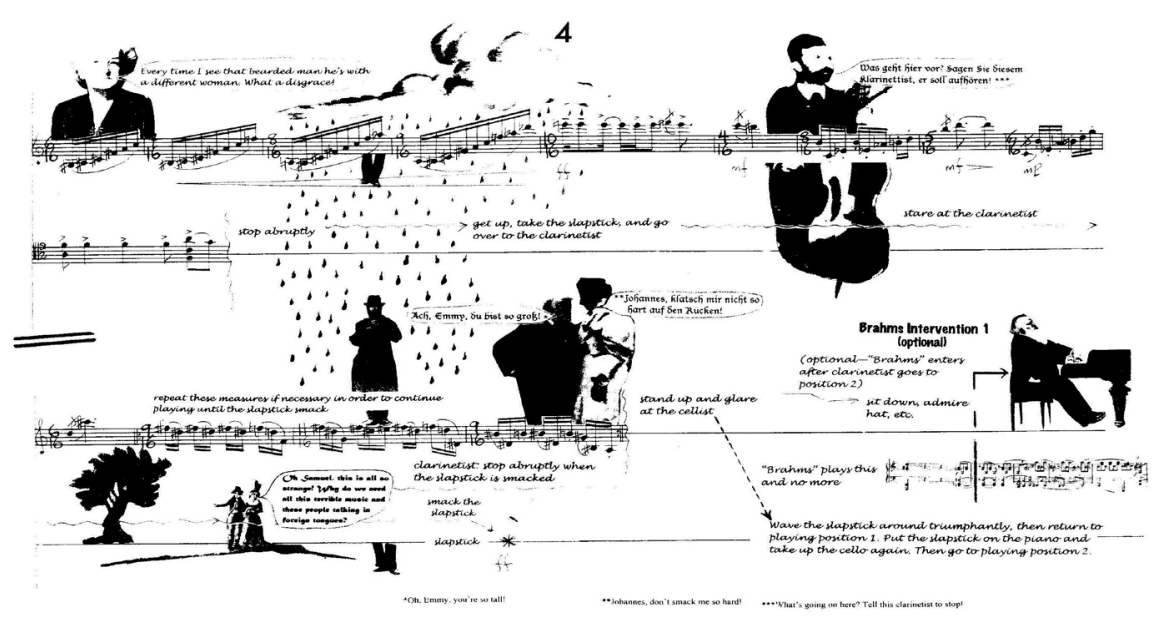

Figure 3. Cherney, Brahms and the German Spirit, 4

At the point shown in the illustration (figure 3), the cellist stops playing and produces a slapstick with which he is told to "smack" at the clarinetist. The Brahms character is depicted flirting with a tall handsome lady and getting ready to play the first of several piano "interventions." The cloudburst is a running image suggesting a more sombre note: here and on many other pages, the raindrops fall on various figures in nineteenth-century Jewish dress, including prominently a solo Klezmer clarinet player. Cherney says they represent the "black flakes" in a poem with that title by Paul Celan, symbolizing the eradication of Jewish culture in Eastern Europe beginning in the Germany and Austria of Brahms's time.

A few days before my ninetieth birthday, in March 2017, I received from Brian an intriguing "Birthday Greeting." I would like to share it with you (figure 4). Here are five short musical passages, two of them, for flute and "imaginary harp," joined as if meant to be played together. A third passage, for piano, has the same barring, tempo, and length, but is not joined to (or even adjacent to) the first two, making it unclear whether it should play with them or independently. The tempo for these three parts is ninety to the sixteenth-note, and each part contains five bars with a total of eighteen sixteenths. In the upper right of the page the Hebrew word chai appears, with an explanation that this word means both "eighteen" and "life." The piano plays its passages in a "somewhat sprightly" fashion, five times, and a note reminds us that eighteen times five is-yes, it's ninety. The remaining two passages are for "flute ad lib." presumably a different instrument from the one at the top of the page, and bassoon. The "flute ad lib." is directed, "be your own person," with an added note at the end, "don't stop for quite a while," and the bassoon is told, "don't pay much attention to the piano." The tempo for the flute is ninety to the eighthnote and for the bassoon (like the others) ninety to the sixteenth-note. 


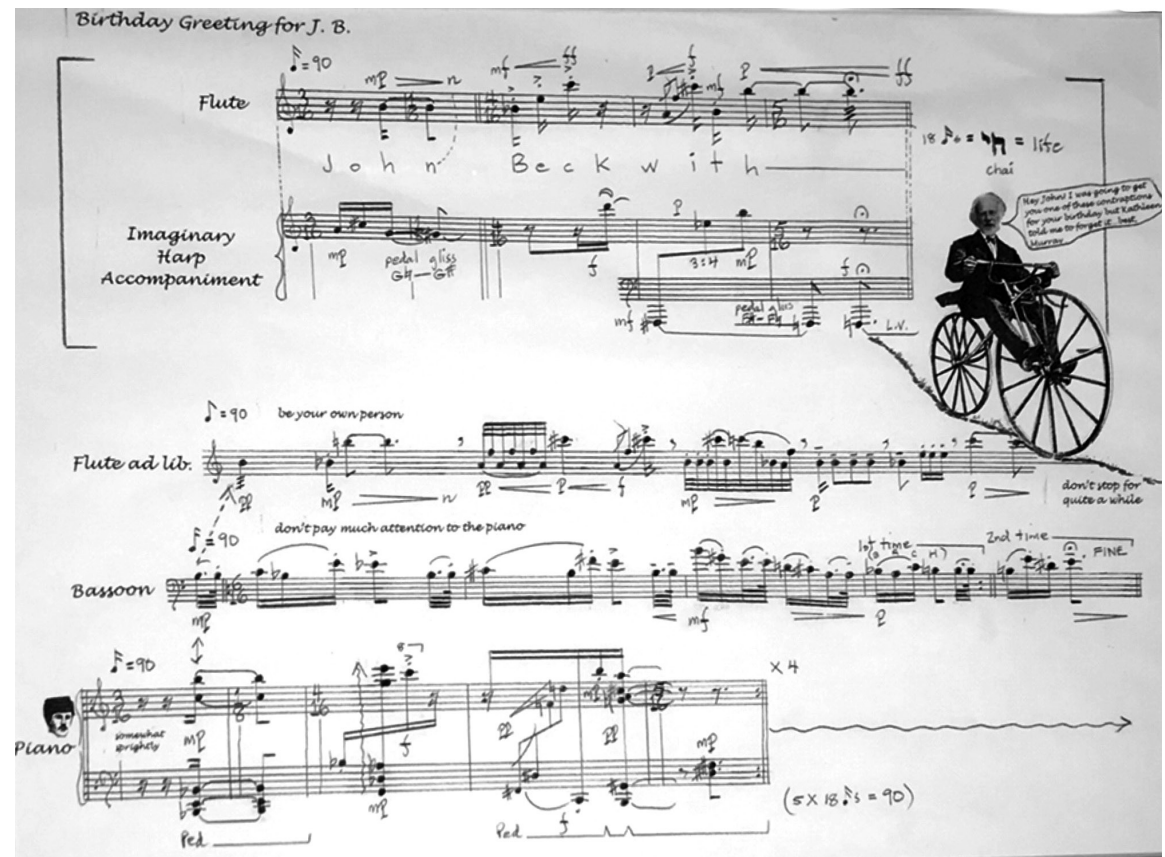

Figure 4. Cherney, Birthday Greeting for J.B., 2017

A figure representing R. Murray Schafer rides off the page on a strangelooking bicycle, and there is another cut-out face, unidentified, alongside the piano line. The top flute line attempts to spell my name in musical notation. $J$, $O, K$, and $W$ are all depicted as sixteenth-note rests. $N$ becomes the end of a diminuendo sign—so, short for "niente." The lower-case $i$, dotted, is a high C\# with a staccato dot. The bassoon part quotes a distorted version of a devastatingly well-known tune, "Happy Birthday," and ends with a familiar musical acrostic, "B-A-C-H."

The two flute lines both employ the same seven pitch classes (that is, the same seven note-names), in a similar though not identical order. The harp part employs nine pitch classes, the first four being a transposition of the first four of the flute. The bassoon and piano parts both refer to this four-note sequence among a wider selection of pitch classes, eleven for the bassoon, twelve for the piano.

I have spent many relaxed moments with this document, enjoying its nuttiness, marvelling at its meticulous realization, and trying to solve further mysteries in its message. I treasure it as a personal example of this original streak in Brian's musical personality.

\section{Compositions by Brian Cherney Cited}

1978: Group Portrait-with Piano

1979: Trois pièces desséchées en forme de sandwich

1980: Dans le crépuscule d'un souvenir 
1983: In the Stillness of the Seventh Autumn

1985: String Quartet no. 3

1991: Quelquefois, à l'ombre de la nuit au lointain

1994: Die klingende Zeit

1995: String Quartet no. 4

2000: String Quartet no. 5

2006: Quelques espaces entre les anges et la terre

2007: An Unfinished Life

2009: String Quartet no. 6; Brahms and the German Spirit

\title{
REFERENCES
}

Beckwith, John. 1975. "Music Criticism." Globe and Mail, 7 October.

Beckwith, John, and Brian Cherney, eds. 2011. Weinzweig: Essays on His Life and Music. Waterloo, ON: Wilfrid Laurier University Press.

Cherney, Brian. 1973. "The Bekker-Pfitzner Controversy (1919-1920): Its

Significance for German Music Criticism during the Weimar Republic (1919-1932)." PhD diss., University of Toronto.

—.1975. Harry Somers. Canadian Composers / Compositeurs Canadiens, I. Toronto: University of Toronto Press.

.2002. Die klingende Zeit (score). Saint-Nicolas, QC: Doberman-Yppan.

Kraglund, John. 1975. "A Theme Lost in Pedantry." Globe and Mail, 27 September.

MacKay, Gillian. 2006. "A New Composition for Wind Ensemble." Canadian Music Educator 47 (4): 10.

Middleton, Neil. 2008. "Hidden Meaning in Brian Cherney's Die klingende Zeit." In Compositional Crossroads: Music, McGill, Montreal, ed. Eleanor Stubley, 227-45. Montreal and Kingston: McGill-Queen's University Press.

\begin{abstract}
This article includes comments on some of Cherney's compositions, and an account of his work on Weinzweig: Essays on His Life and Music (Waterloo: Wilfrid Laurier University Press, 2011), of which he and John Beckwith were the co-editors. Cherney's approach to composing equips him for dealing with a wide range of musical questions, and his exceptional command of both German and Jewish history (as evidenced, for example, in his University of Toronto dissertation on the Bekker-Pfitzner controversy of 1919, and in his essay on the sources of Weinzweig's radicalism in the 2011 publication) has in turn suggested avenues of exploration in his creative work. Further observations touch on his gift for parody and musical in-jokes.
\end{abstract}

\section{RÉSUMÉ}

Cet article inclut des commentaires sur certaines compositions de Cherney et un compte rendu de sa contribution à l'ouvrage intitulé Weinzweig: Essays on His Life and Music (Waterloo, Wilfrid Laurier University Press, 2011), dont il a été coéditeur en collaboration avec John Beckwith. Son approche de la composition prépare bien Cherney au traitement d'un vaste éventail de questions musicales, tandis que sa connaissance 
poussée de l'histoire de l'Allemagne et des Juifs (que révèlent par exemple sa dissertation présentée à l'Université de Toronto sur la controverse Bekker-Pfitzner de 1919 et son essai sur les sources du radicalisme de Weinzweig incluse dans la publication de 2011) révèle des pistes d'exploration dans son travail de création. D’autres observations portent sur son don pour la parodie et les blagues musicales pour initiés.

\section{BIOGRAPHY}

John Beckwith, composer, music educator, writer, and editor, was born in Victoria in 1927. He received his musical education in Toronto (1945-50) and Paris (1950-2). He was appointed to the Faculty of Music, University of Toronto, in 1952 and served as the dean $1970-77$ and as the first director of its Institute for Canadian Music from 1985 until his early retirement in 1990 . He has written more than 160 compositions, three books, and many articles on music. 